Journal of Management and Economic
Studies
2019, 1(1): 16-33 DOI: $10.26677 / \mathrm{TR} 1010.2019 .58$
Journal Homepage: $h$ ttps://www.jomaes.org

\title{
Banks Business Models, Risk Management Systems And Small And Medium Enterprises Financing Proclivity In Zimbabwe
}

\author{
Watson Munyanyi \\ Great Zimbabwe University wmunyanyi@hotmail.com \\ Tafirei Mashamba \\ Great Zimbabwe University tmashamba@gzu.ac.zw
}

\begin{abstract}
The need to create sustainable ways of generating profits has put substantial pressure on banks to reinvent their business models in the post-global financial crisis era. The objectives of bank managers, which include profit maximization, essentially influence the bank's lending behavior, scale, choice, and timing. Among the constraints that small and medium businesses face is limited access to financing. An increase in bank involvement in the financing of small and medium enterprises is critical for the survival of the sector. Given the widespread heterogeneity in banks business models globally, this study, grounded on the Portfolio Management Theory, investigates how diversity in business models affects bank risk management systems and their proclivity to small and medium enterprises lending. Structural equation modeling, a confirmatory, multivariate technique, was employed to analyze the causal relationships between these variables, starting with a pictorial representation of the variables. The strong relationship between the variables under study suggests that business models and risk management systems are key components in the decision to lend to small and medium enterprises. As such there is need for banks to reconsider their business operations mechanisms in order to accommodate the small and medium enterprises sector.
\end{abstract}

Keywords: Business Model, Risk Management, SME Financing, Financial Performance, Value Creation

\section{INTRODUCTION}

The need to create sustainable ways of generating profits has put substantial pressure on banks to reinvent their business models in the post-global financial crisis environment (Kok, Móré \& Petrescu, 2016). In addition, globalisation and changes in the regulatory and monetary policies also contribute to the need to shift a banks' business models (Gehrig, 2015). In recent years, banks business models transformed and became more heterogeneous than ever before and this is predominantly apparent in global banks (Hryckiewicz \& Kozłowski, 2017). For example, 
Asian banks underwent a remarkable shift in competitive conditions and strategy, because of both the Asian financial crisis of 1998

and the global financial crisis (Olivero, Li, \& Jeon, 2011). Over and above bank-specific changes that occurred, financial deregulation and innovation also led to transformations of the credit markets and the bank lending channels (Perera, Ralston, \& Wickramanayake, 2014). The assetliability structures of international banks show investment banking models that comprise primarily of trading assets and market funding, while other banks have preferred to concentrate on different strategies (Hryckiewicz \& Kozłowski, 2017). Because of the general increase in the level of liquidity risk, banks have also grown to favour 'safe loans', thereby alienating SMEs, who already suffer from under diversified sources of finance (Holton, Lawless \& McCann, 2011; Ivashina and Scharfstein, 2010). Most banking institutions highlight factors such as unavailability of collateral, failure to prove creditworthiness, insignificant cash flows, lack of sufficient credit history and poor and undeveloped bank-borrower relationships as factors that make it difficult for them to advance financing to SMEs (Ardic, Mulenko \& Saltane, 2012; Osano \& Languitone, 2016). In addition, management of risk is also an important factor in lending decision, since risks that affect banks may affect the economic performance and professional reputation of the firm as well as environmental, safety, and societal outcomes (Rebelo, Silva \& Santos, 2017).

A business model specifies how a firm will generate revenue from the provision of products and services hence, it defines how a business will create and capture value (Boons and LüdekeFreund, 2013). It defines what benefit a business will bring to customers; how it will deliver the benefit, and how it will create value (Teece, 2010; Chesbrough \& Rosenbloom, 2002). While the notion of business model arose from competition-oriented business environments, it is imperative that all businesses to incorporate business models fundamental components in their strategic planning (Ranerup, Henriksen and Hedman, 2016). Several empirical studies have been carried out focusing on the relationship between business model and factors such as capital (Wheelock \& Wilson, 2000), operational efficiency (Kwan \& Eisenbeis, 1997), sources of finance (Demirgüc-Kunt \& Huizinga, 2010), securitisation and financial markets (Mian \& Sufi, 2009), corporate governance (Laeven \& Levine, 2009) and diversification (Stiroh, 2010). Given the widespread heterogeneity in banks' business models globally, this study poses the question, how does diversity in business models affects bank risk management systems and SMEs lending proclivity. Existing literature has tended to define banks business models basing either on a relative examination of balance sheets (Blundell-Wignall \& Atkinson, 2010) or on group analysis on single assets and liability transactions (Ayadi \& de Groen, 2014). However, such methods fail to incorporate the influence of non-financial information in the crafting of banks business models. In addition, the methods do not capture the socioeconomic and other aspects like customer relations, value creation and environmental factors, that are part of a bank's business model. While there is almost ample research seeking of clarify the business models construct, their significance in relation to strategic decision making and the creation of value remains unresolved (Casadesus-Masanell and Ricart, 2010; Teece, 2010). Research is still limited regarding the influence of business models and risk management systems on the lending decisions of banks towards SMEs.

\section{LITERATURE}

\subsection{Theoretical Foundation}

This study is grounded on the Modern Portfolio Theory (MPT) developed by Harry Markowitz in 1952. The theory argues that there is an unlimited number of "efficient" portfolios that occur along the efficient-frontier curve which consists of those portfolios that either maximise return 
or minimise risk (Todoni, 2015). The MPT therefore advocates that firms minimize portfolio risk on a specific expected return by properly deciding on the essentials of the portfolio (Markowitz (1952). It is against this advocacy to the portfolio theory that this research seeks to investigate the influence of business models on lending decisions while considering the moderating role of risk management systems.

\subsection{Business Models}

The notion of business models has gained growing interest among management practitioners and academics since the mid-1990s (Huijben and Verbong, 2013). Understanding how to develop a suitable business model has become integral for a firm to remain competitive and operate profitably (Porter, 1996). Literature on business models has focused predominantly on the way in which businesses organize themselves to create and compete from their activities (Bolton \& Hannon, 2016). Therefore, a business model, which represents how a business creates, delivers, and captures value, is the logic behind the creation of both public value for society and revenue for the business (Janssen and Zuiderwijk, 2014). There are generally nine business model 'building blocks' namely key partners, key activities, key resources, customer value proposition, customer relationships, channels, customer segments, cost structure and value capture (Osterwalder and Pigneur, 2010). The way businesses interpret these business model dimensions determines its sustainability (Rauter, Jonker and Baumgartner, 2015). It becomes an abstract tool that describes the interrelated activities in the process of interacting with customers, associates and merchants and it determines how successful a business creates, captures, and delivers value (Osterwalder \& Pigneur, 2010; Bocken, Short, Rana and Evans, 2014; Zott and R. Amit, 2010). According to Boons and Lüdeke-Freund (2013) a basic business model outline is a combination of value propositions, customer interface and the financial model and this allows for creation of a competitive edge.

In essence, a business model is a description of the benefits that a venture hopes to deliver to customers, how it will deliver and value will be captured in the process (Chesbrough and Rosenbloom, 2002). A business model pronounces the logic, data, and other indications as to how a business generates and brings value to customers and it is only when a company identifies means of capturing value that they can bring benefits to their customers through innovation (Teece, 2010; Friedrich von den Eichen, Freiling and Matzler, 2015). The determination of how a firm delivers value is central in designing a business model (Teece, 2010; Boons and Lüdeke-Freund, 2013) and the ability create and capture value is well-defined by a firm's business model (Øiestad and Bugge, 2014; Baden-Fuller \& Morgan, 2010). Firms create their business models in response to changes in technologies, regulatory frameworks, competitor behavior and customer demands (De Reuver, Bouwan \& Haaker, 2009).

\subsection{Risk Management Systems}

Steinherr (1998) considers risk management to be one of the most significant innovations of the 20th century. The decision theory states that risk is any uncertain component of an action, event or a process that has potentially detrimental and irreversible effects (Oprean, 2014). The occurrence of the global financial crisis in 2008, whose consequences were regarded as the worst since the Great Depression, has put financial institutions under the microscopic lens of policymakers and financial economists (Ibrahim, 2016). There some various forms of risks that affect the operational processes of firms including quality risks, environmental risks, health and safety risks and information security risks and firms must strive to create healthier operational environments where risks is minimized (Qi, Qingling, Wei \& Jine, 2012). Nowicki (2013) suggests that a critical component of organisational strategy is the minimization of business risk to levels that ensure the competitiveness of the firm in the market. The identification, 
assessment and minimization of hazards and risks should be aimed at mitigating the impact risk on operations, products and services, infrastructure, and the business (Rebelo \& Santos, 2014). The process of risk management is aimed at identifying and assessing risk with the aim of applying suitable methods to reduce the negative effects of risk and help firms better manage their operations (Tohidi, 2011).

There is a wide range of factors that are considered in risk management from the economic, economic, political and competitive, to the level of technological and financial development (Oprean, 2014). The overall objective of risk management is to provide the firm with the much needed information to lessen risks and alleviate the negative impact of risk on the firm's activities and stakeholders (Rebelo, Silva \& Santos, 2017). In addition, Agarwal and Hauswald (2010) recommend that progression in technology related to credit scoring permits banks to overcome limitations in lending as well as hardening soft information. Such rating-based credit risk assessment models have been widely by financial institutions in granting loans (Guo, Zhou, Luo \& Xiong, 2016). Risk management activities include the selection and implementation various measures aimed at modifying the risk the business is likely to face (Szczepański \& Światowiec-Szczepańska, 2012). The major activity in risk management involves limiting risk through controlling, and the other activities include risk evasion, risk transfer and the use of insurance to finance risk (Chapman, 2008). The effectiveness of the control mechanisms is measured by the extent to which a risk is eradicated or limited after the introduction of the measures. Measures of risk in banks include loans-to-assets ratio and the equity to assets ratio which measures the general capital strength in a bank while indicating the bank's capital adequacy and stability level (Paulet, Parnaudeau \& Abdessemed, 2014).

\subsection{SME Lending Decisions}

Small and medium enterprises (SMEs) contribute significantly to a country's economic growth (Paul, Parthasarathy and Gupta, 2017). SMEs worldwide are responsible for the creation of many jobs and income opportunities for the poor thereby contributing to poverty alleviation and economic growth (Ayyagari, Demirgüç-Kunt and Maksimovic, 2011; Edoho, 2015). Like many developing countries, Zimbabwe is experiencing a significant rise in the number of SMEs in recent years (Macheka, Manditsera, Ngadze, Mubaiwa and Nyanga, 2013). The country's black empowerment and indigenisation laws that culminated at independence in 1980 contributed to the growth of SMEs across sectors in the country (Nyangara, 2013). Despite the significant role that SMEs play in economic development, these SMEs continuously encounter hindrances particularly in developing countries (Bouazza, Ardjouman and Abada, 2015). Access to finance by SMEs is largely cited as the greatest obstacle to SMEs development and as a result it has attracted the attention of academics and policy makers (Ardic, Mylenko and Saltane, 2012; Osano and Languitone, 2016). SMEs are unable to access bank financing because of lack of required collateral, limited awareness of funding opportunities and limited business support services.

Recently, there has been a renewed research interest the area of SME financing, considering the growth in the globalisation of financial markets (Stevenson \& Pond, 2016). The procyclicality of bank lending post-global crisis created unwanted response effects that reduced economies' allocative efficiency (Behr, Foos \& Norden, 2017). Additionally, the global financial crisis of 2008-2009 brought about a negative shock to the growth of bank lending and consequently, SMEs access to financing, which is characterized by information asymmetry, was negatively affected (Cull \& Pería, 2013). Existing literature strongly supports the notion that availability of finance is critical in the decision to undertake an entrepreneurial venture (Abe, Troilo \& Batsaikhan, 2015). SMEs presently do not have adequate resources take up innovative developments and improve growth opportunities (Paulet et al., 2014). SMEs access to financing 
in developing largely depends on several internal and external firm factors (Berg \& Schrader, 2012).

The objectives of a bank, which include profit maximization essentially, influence the bank's lending behavior, scale, choice, and timing (Behr, Foos and Norden, 2017). In this context, smaller banks are generally willing to consider financing small firms than relatively large banks (Canales and Nanda, 2012). In many countries, monetary authorities have sought to encourage banks to lend to SMEs as a way of promoting the sector's growth (So, Thomas \& Huang, 2016). Yet, asymmetric information, inadequate collateral and inexperienced managers are some of the challenges that restrict SMEs access to bank financing (Shaban, Duygun and Fry, 2016). In addition, banks sometimes avoid advancing financing to some SMEs like young start-ups even though they exhibit the possibility of high returns because of the possibility of risk of loss (Muller, Gagliardi, Caliandro, Bohn and Klitou, 2014). That said, this paper explores how business models and risk management systems influence banks' decisions to lend to SMEs.

\subsection{Conceptual Model And Hypothesis Development}

A review of existing literature led to the development of the following conceptual model. The conceptual model is a pictorial representation of the hypotheses proposed and the relationships being investigated in the broader research. Figure 1 summarizes the proposed theoretical relationship between the variable under study.

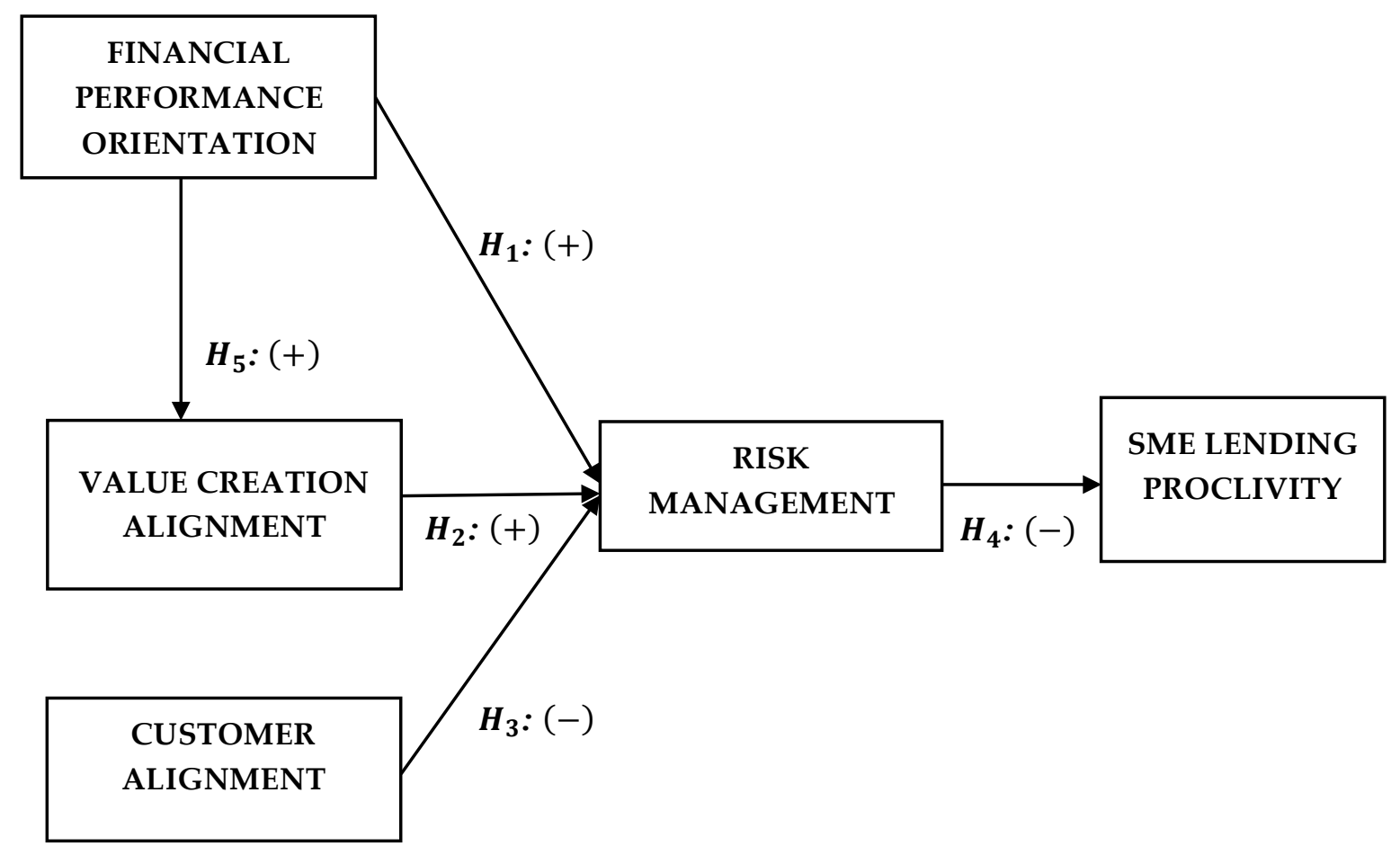

Figure 1: Conceptual Model

\subsubsection{Financial Performance Orientation and Risk Management Systems}

Financial performance can be defined as the ability of firms to operate competently and profitably, to survive and grow while reacting well to the opportunities and threats in the business environment. In this study, financial performance was measures using and instrument adapted from Moorman and Rust (1999) that basically measured financial performance subjectively. Return on assets, net profits, sales, and market share were the main issues 
included into the measurement instrument. Currently organisations are facing increasing global competition coupled with growing while changing customer demands for product innovativeness and supplier sensitivity and these factors transformed firms' business models while reducing the incentive for banks to take up new risks (Chan and Qi, 2003). The uncertainty in the business environment makes it difficult to monitor risk in certain investment assets (Szczepański and Światowiec-Szczepańska, 2012). One of the firm's motives for managing risk is to ensure the stability of earnings and cashflows and the reduction in risk allows the firm to make better forecasts and avoid financial distress and its consequences (Dhanini, 2007; Drogt \& Goldberg, 2008). Failure to manage risk or misjudging a risk has catastrophic consequences, to the firm extending from customer loss to bankruptcy (Hollman \& Mohammad-Zadeh, 1984). Risk management significance in banks and other financial intermediaries is magnified because of the position that these occupy in the economy and the fact that intermediation itself is a source of other risks (Sharma, 2008). An understanding of risks and mechanisms to prevent them helps preserve and improve competitive position (Oprean, 2014). Existing literature has shown that banks in their business models can combine their daily activities with improvement in profitability, while minimising risk (Hryckiewicz \& Kozłowski, 2017). Given the arguments above, this study proposes the following hypothesis.

\section{$H_{1}$ : Financial Performance oriented business models are significantly and positively related to risk management systems in SMEs lending.}

\subsubsection{Value Creation Alignment and Risk Management Systems}

The notion of value creation has over the years remained a central issue in corporate strategy development (Tuch and O'Sullivan, 2007). The value creation process, as contained in the dynamic capability theory, focuses on how firms revive or alter their resources persistently to improve their well beings (Eisenhardt \& Martin, 2000; Teece, 2007). It involves reconfiguring the consumers' perception on the worthiness of a product or service (Priem, 2007). The process of reconfiguring the firm's core processes carries a risk in that the implementation of new manufacturing processes for example, may alter standard product specification leading to product unacceptability in different national markets or consumer groups (Schoenberg \& Bowman, 2015). Commercial banks now face competition from investment banks, mutual funds and insurance companies who have incorporated commercial banks' core business activities into their own (Olivero, Li, \& Jeon, 2011). When banks, particularly those in growing economies with limited domestic markets, expand their operations to new geographical markets, they are presented with opportunities for both growth and value creation ( $\mathrm{Lu}$ and Beamish, 2001). As banks undertake to expand their activities, they expose themselves to risk such as liquidity risk (Jenkinson, 2008) thereby negatively affecting profitability of the bank (Chaplin, Emblow \& Michael, 2000). Undoubtedly, there is a link between investment decision making, banking system development, firm value and risk management and given this interconnectedness, it is imperative that this study proposes the following hypothesis.

\section{$\mathrm{H}_{2}$ : Value creation business models are significantly and positively related to risk management systems in SMEs lending.}

\subsubsection{Customer Alignment and Risk Management Systems}

Scholars have thrown some doubts on the notion that banks always make the best lending decisions that always lead to the competent distribution of credit. Such scholars have argued that the customer should not be 'forgotten' in the discussion of lending decisions (Heo \& Lee, 2011). As banks continue to compete for deposits in the competitive environment they are bound to alter their funding decisions and costs (Sääskilahti, 2016). Competition, increasing costs of customer acquisition and growing customer switching tendencies, have forced many 
banks to adopt a strategic emphasis on customer retention (Ennew and Binks, 1996; Manrai and Manrai, 2007). One critical component of bank lending decisions is information asymmetry between lender and borrower and banks have developed closer relationships with their customers to reduce such informational irregularities (Boot, 2000). Banks also manage their costs by cross selling different financial products to the same customer hence the need to reinforce the relationships with customers and foster customer loyalty (Bonini, Dell'Acqua, Fungo and Kysucky, 2016). There are numerous other evident benefits to banks for maintaining long-term relationships with its customers (Ying and Yuande, 2013). Profitability and competitive advantages are gained through ensuring quality relationships exist between banks and their customers, given the level of competition in the banking industry and a dwindling customer base (Ndubisi, 2007; Izogo, Reza, Ogba and Oraedu, 2017). Concisely, sustaining good customer relationships and continuous patronage is regarded as critical for organisational success (Izogo, 2016; Ndubisi Khoo-Lattimore, Yang and Capel, 2011). In this respect, banks find themselves having to trade off tight risk management systems for customer loyalty and retention because such relationships impact banks performance (Hasana, Jackowicz, Kowalewski and Kozłowski, 2017). Based on the above, the following research hypothesis is proposed.

\section{$\mathrm{H}_{3}:$ Customer aligned business models are negatively related to risk management systems in SMEs lending.}

\subsubsection{Risk Management Systems and SMEs Lending Proclivity}

Banks' lending decisions are based on some process that is meant to overcome operational problems that have the potential to affect the viability of bank (Ashton and Keasey, 2003). One factor that has limited SMEs to access bank financing is information opacity, which is generally high in the young who generally do not have audited financial statements and thus they lack the financial information needed to make an informed decision on a business loan application (Hasana, Jackowicz, Kowalewski and Kozłowski, 2017). The greater probability of default prevalent among SMEs force banks to reduce the amount of credit advanced to these firms (Behr, Foos and Norden, 2017). SMEs are generally considered as riskier, more financially constrained and more bank-dependent than large firms and as such traditional methods of risk management may not be favorable for lending to SMEs (Ashton \& Keasey, 2003). Bank lending to SMEs is always affected information asymmetries and its unattractive risk management practices (Behr, Foos \& Norden, 2017). Accordingly, the following research hypothesis is formulated:

\section{$\mathrm{H}_{4}$ : Risk management systems are significantly and negatively related to SME bank lending proclivity}

\subsubsection{Financial Performance Orientation and Value Creation Alignment}

Because of a series of company failures, product failures, stock market pressures, brand collapses and increased competition in the market, that the world has experienced, the notion of value creation has become a global issue (Lau and Tong, 2008; Prahalad and Ramasamy, 2004). In a dynamic and competitive business environment, the essential logic for value creation is also changing, making strategic thinking critical for survival (Acharyulu and Shekhar, 2012). Value is created in an organisation through the transformation of organisational inputs into short and long term outputs and outcomes for the benefit of firm stakeholders, society, and the environment (Abdullah and Said, 2015). Anderson et al (2014) have concluded that firms that understand and consider value creation at their management controls will yield better economic and behavioral aspects. Each mode of value creation corresponds with a set of value creation activities and these activities affect the internal structure of the organisation (Kraaijenbrink and 
Spender, 2011). Existing literature has shown that there is a positive relationship between value creation and business performance (Fuller, 2001; Gholami, 2011; Kraaijenbrink and Spender, 2011). Given these elements, we propose the following hypothesis:

\section{$H_{5}$ : Financial performance oriented business models are significantly and positively related to value creation alignment.}

\section{METHODS OF THE STUDY}

\subsection{Sample and Data Collection}

The target population of the study is commercial banks. As of 31 December 2016 they were 13 registered commercial banks. Per each institution, questionnaires were distributed to owners/managers, loan officers/credit controllers and branch managers, considering that they are actively and meaningfully involved in the operational functions of the lending institutions. Data for this study was collected using self-administered questionnaires from a sample of 13 institutions (450 respondents) and of these, 273 questionnaires were returned and analysed after cleaning. The response rate was acceptable as it aligned well with the requirements for structural equation modelling (SEM), which requires a sample size of 200 or more observations (Hair, Black, Anderson \& Babin, 2010).

\subsection{Data Analysis and Results}

Structural equation modeling (SEM) was used to statistically analyse the relationship between variable as it provides a more vigorous methodology for testing causal models (Kline, 2004). SEM is a technique that specifies, estimates, and evaluates linear relationships between a set of latent and observed variables (Byrne, 2001; Shah and Goldstein, 2006). SEM has the ability to examine multiple relationships simultaneously and allows for measurement errors. AMOS version 24.0 was use for SEM and a two-step model building method was employed, where measurement properties are validated first, then the structural model (Joreskog and Sorbom, 1993).

\subsection{Sample Description}

The demographic profiles of the research participants are presented in Table 1. Most the respondents have a meaningful academic qualification with most of them (49.45\%) having a professional qualification. This strengthens the findings of this research because at least it can be concluded that the respondents understood the questions and gave reasonable responses. Most of the respondents are directly involved in the lending process. $52.01 \%$ are credit controllers or analysts and $30.04 \%$ are loan officers. The research was on lending decisions and these are the best people to relate to on such issues. The involvement of Management in the research also validate the findings are these are responsible for managerial functions like business modelling and risk management. For note is the fact that there were more male respondents than female respondents. 
Table 1 Sample Demographic Characteristics

\begin{tabular}{|c|c|c|c|c|c|}
\hline Highest Level of Education & Freq & $\%$ & Position in Bank & Freq & $\%$ \\
\hline Doctorate & 2 & 0.73 & Management & 28 & 10.26 \\
\hline Postgraduate Degree & 15 & 5.50 & Credit Controller/Analyst & 142 & 52.01 \\
\hline Undergraduate & 102 & 37.36 & Loan Officer & 82 & 30.04 \\
\hline Professional Qualification & 135 & 49.45 & Bank Teller & 5 & 1.83 \\
\hline High School & 19 & 6.96 & Other & 16 & 5.86 \\
\hline Total & 273 & 100 & Total & 273 & 100 \\
\hline Participants Work Experience & Freq & $\%$ & Gender & Freq & $\%$ \\
\hline$\leqq 2$ years & 85 & 31.14 & Male & 153 & 56.04 \\
\hline $3-5$ years & 98 & 35.90 & Female & 120 & 43.96 \\
\hline $6-10$ years & 56 & 20.51 & Total & 273 & 100 \\
\hline $11-20$ years & 23 & 8.42 & & & \\
\hline$\geqq 21$ years & 11 & 4.03 & & & \\
\hline Total & 273 & 100 & & & \\
\hline
\end{tabular}

\subsection{Validation of measures}

In both exploratory and confirmatory studies, survey instruments are commonly subjected to reliability and validity inspections (Collis \& Hussey, 1995) and this measurement instrument validation is somehow a precondition to testing a model and research hypotheses (Shan \& Jolly, 2013). Reliability of an instrument relates to the constancy and consistency of an instrument in measuring a variable (Page \& Meyer, 2000; Sekaran, 2003). In this study, scale reliability, convergent validity and discriminant validity were assessed. convergent validity was determined by calculating item reliability, internal consistency, and average variance extracted (AVE) (Fornell \& Larcker, 1981) while convergent validity and discriminant validity were assessed using confirmatory factor analysis.

Item reliability assesses the loadings for each individual item. The loadings indicate the correlation of the items with their respective constructs. Table 2 presents the detailed item loadings, internal consistency and the average variance extracted. A factor loading that is above 0.60 is regarded as high enough hence significant to explain variations in the variable (Johnson \& Wichern, 2002). The item loadings from this study ranged between 0.714 and 0.889 making them acceptable and hence all items were significant in explaining the variations in the variables. Regarding internal consistency, Fornell and Larcker (1981) stipulate that the minimum acceptable value is 0.7 . They also add that the AVE value must be greater than 0.5 to be acceptable. The results contained in Table 2 indicate that all the variables have internal consistency values above 0.7 value and AVE values above 0.5 . This implies that convergent validity of the measurement properties was achieved. 
Table 2 Item Loading, Composite Reliability (Cr) And Average Variance Extracted (AVE)

\begin{tabular}{|c|c|c|c|c|}
\hline Construct & Item & Loading & $\mathbf{C R}$ & AVE \\
\hline \multirow{4}{*}{ Financial Performance Orientation (FPO) } & FPO1 & 0.850 & \multirow[t]{4}{*}{.916} & \multirow[t]{4}{*}{.733} \\
\hline & FPO2 & 0.889 & & \\
\hline & FPO3 & 0.805 & & \\
\hline & FPO4 & 0.878 & & \\
\hline \multirow{4}{*}{ Customer Alignment (CA) } & CA1 & 0.745 & \multirow[t]{4}{*}{.843} & \multirow[t]{4}{*}{.573} \\
\hline & CA2 & 0.758 & & \\
\hline & CA3 & 0.714 & & \\
\hline & CA4 & 0.801 & & \\
\hline \multirow{4}{*}{ Value Creation (VC) } & VC1 & 0.637 & \multirow[t]{4}{*}{.800} & \multirow[t]{4}{*}{.501} \\
\hline & VC3 & 0.612 & & \\
\hline & VC4 & 0.752 & & \\
\hline & VC6 & 0.622 & & \\
\hline \multirow{4}{*}{ Risk Management Systems (RMS) } & RMS1 & 0.829 & \multirow[t]{4}{*}{.672} & \multirow[t]{4}{*}{.891} \\
\hline & RMS2 & 0.819 & & \\
\hline & RMS3 & 0.824 & & \\
\hline & RMS2 & 0.808 & & \\
\hline \multirow{4}{*}{ SME Lending Proclivity (SLP) } & SLP1 & 0.664 & \multirow[t]{4}{*}{.811} & \multirow[t]{4}{*}{.520} \\
\hline & SLP2 & 0.687 & & \\
\hline & SLP3 & 0.701 & & \\
\hline & SLP4 & 0.821 & & \\
\hline
\end{tabular}

Another important assessment measure is discriminant validity. Discriminant validity relates to the extent to which two theoretically comparable variables are different (Hair et al., 1998). As advocated for by Barclay, Higgins, and Thompson (1995) discriminant validity is established when the square root of the AVE is greater than the inter-constructs correlations. The results in Table 3 prove that adequate discriminant validity of the measurement model was established. The constructs in this measurement model do differ from each other.

Table 3 Correlation Of Latent Variables And Square Roots Of Ave

\begin{tabular}{lccccc}
\hline \multicolumn{1}{c}{ Construct } & FPO & CA & VC & RMS & SLP \\
\hline Financial Performance Orientation (FPO) & $\mathbf{0 . 8 5 6}$ & & & & \\
Customer Alignment (CA) & -0.182 & $\mathbf{0 . 7 5 7}$ & & & \\
Value Creation (VC) & 0.386 & -0.020 & $\mathbf{0 . 7 0 8}$ & & \\
Risk Management Systems (RMS) & 0.399 & -0.226 & 0.615 & $\mathbf{0 . 8 2 0}$ & \\
SME Lending Proclivity (SLP) & 0.330 & 0.141 & 0.362 & -0.493 & $\mathbf{0 . 7 2 1}$ \\
\hline (The bold elements in the main diagonal are the square roots of $A V E)$ & & &
\end{tabular}




\section{RESULTS}

\subsection{Research Model Assessment and Tests of Hypotheses}

Model fitness was also assessed and the hypothesis tested. For the model to be regards as fit, the CFI values should be between 0 and 1 and the closer the number is to 1 the better the model fit and a CFI value of 0.90 or greater indicated an acceptable model fit (Hu \& Bentler, 1999). The Root Mean Square Error of Approximation (RMSEA) estimates are also used to assess model fitness and a RMSEA of 0.06 or less indicates a satisfactory model fit (Hu \& Bentler, 1999). The results reported below Table 4 show that the model is satisfactory in terms of general goodness of fit. The results show that, CFI was 0.918), and RMSEA was 0.056 and consequently thresholds were achieved (Bentler, 1990). The results of the hypotheses testing are detailed in Table 5. All the 5 hypotheses stated in the conceptual model were supported.

Table 4 Structural Model Hypotheses Result

\begin{tabular}{lc}
\hline Hypothesis & Path Coefficient \\
\hline$H_{1}: \mathrm{FPO} \rightarrow \mathrm{RMS}$ & $0.162^{*}$ \\
$H_{2}: \mathrm{VC} \rightarrow \mathrm{RMS}$ & $0.651^{*}$ \\
$H_{3}: \mathrm{CA} \rightarrow \mathrm{RMS}$ & $-0.234^{*}$ \\
$H_{4}: \mathrm{RMS} \rightarrow \mathrm{SLP}$ & $-0.264^{*}$ \\
$H_{5}: \mathrm{FPO} \rightarrow \mathrm{VC}$ & $0.481^{*}$ \\
\hline
\end{tabular}

Note: GFI=0.882; AGFI=0.852; IFI=0.918; TLI $=0.900 ; \mathrm{CFI}=0.918 ;$ RMSEA $=0.056 ;{ }^{*} \mathrm{p}<0.01$.

\subsection{DISCUSSIONS AND CONCLUSIONS}

This study made use of the Modern Portfolio Theory to provide a theoretical grounding for the conceptual model to examine the impact of business models on SMEs lending proclivity by banks, as well as the mediating role of risk management systems. The study proposed that business models impact on risk management decisions which in turn are negatively related to SME lending tendency. The findings of the study indicate that banks with business models that are more inclined towards increasing financial performance and creating value positively correlate to tighter risk management systems, while those who are customer centric tend to have lighter demands in their management of risk. Banks and microfinance institutions are characteristically profit-oriented and are expected to deliver by their shareholders (Meriläinen, 2016). However, there is evidence of some institutions that exhibit greater customer orientation and tend to be tolerant to the SMEs financing demands. Customers aligned banks tend to have in place lighter risk management demands and as a result tend to lend more to these SMEs. Reasons for customer alignment are summarised by Santos (2009) who states that a closer interface with crucial customers and product end-users does not only enable firms to study their current market needs, but also enable the firm to discover future customer needs ahead of competition. This kind of SME tolerant lending behavior was generally observable among NonGovernmental Organisations backed microfinance institutions and government affiliated specialised banks.

\section{IMPLICATIONS AND RECOMMENDATIONS}

Since financial performance and value creation business model tend to be associated with stringent risk management systems, perhaps it will be beneficial to both banks and SMEs if 
banks alter their business models slightly to enhance fee and commission based activities. From the questions asked to the respondents, the current value creation and financial performance focused business models have meant that banks subject borrowers to rigorous risk assessments and those that pass the test are subjected to high interest rates to compensate for taking up the perceived risk. However, as stated by Kok, Mirza, Móré and Pancaro (2016), a shift to fees and commissions based models result in diversified income sources thus helping banks stabilise their capital generation and become less reliant on net interest income. Once banks are able to expand their fees and commissions generating activities they may eventually be able to reduce the interest rate the demand from SMEs thereby improving on access to financing. While it is not clear whether a stronger dependence on fees and commissions income will fully compensate for lower net interest income, a study by Altunbas, Manganelli and MarquesIbáñez (2011) has shown that fees and commission income tends to be more stable than both net interest income and trading income. This model does not divert much from the ultimate objective of interest income based business models.

The results expose the need for policy makers to promote and incentivize the formation of Savings and Cooperative Banks to enhance SMEs access to debt financing. While commercial and merchant banks as well as micro finance institution are profit oriented, savings and cooperative banks are stakeholder banks and usually they do not have a profit distribution determination; hence, they are not primarily profit-oriented. As argued by Fonteyne (2007) cooperative banks are not shareholder owned but belong to contributing members, who frequently are the customers such that, instead strictly seeking to maximise returns cooperatives may seek to primarily serve their members. The need to educate banking institutions on the significant role the customer plays in value creation is evident from this study. When the focus of a firm is the customer in value engineering, they achieve market success through focused innovation and shared resources, knowledge, and skills. This means that by adopting a more customer aligned business model, the bank's goal of value creation is eventually achieved while satisfying SMEs' financial needs.

An alternative creditworthiness evaluation system may be very handful in ensuring that SMEs access debt financing from banks and microfinance institutions. In Zimbabwe, financial institutions, in pursuance of the financial performance maximization and value creation business models advance loans to SMEs primarily based on past repayment data, something many SMEs do not possess. While such traditional risk management strategies are highly dependable, the use of alternative data from online, mobile, and psychometric sources may also yield similar if not better results. One's willingness and ability can also be determined through a series of psychometric evaluations rather than through submission of audited financial statement and pledging of collateral. This however does not undermine the fact that financial institutions that look to enhance their understanding of their customers, build their business portfolios, and manage risk should make greater use of these alternative data sources, as sources of opportunities and to enjoy the distinct advantages inherent to such data sources. 


\section{REFERENCES}

Abdullah, N. H. N., \& Said, J. (2015). Enhancing the Governance of Government Linked Companies via Strategic Management Accounting Practices and Value Creation. Procedia Economics and Finance, 28, 222-229.

Abe, M., Troilo, M., \& Batsaikhan, O. (2015). Financing small and medium enterprises in Asia and the Pacific.Journal of Entrepreneurship and Public Policy, 4(1), 2-32.

Acharyulu, G. V. R. K., \& Shekbar, B. R. (2012). Role of value chain strategy in healthcare supply chain management: An empirical study in India. International Journal of Management, 29(1), 91.

Agarwal, S., \& Hauswald, R. (2010). Distance and private information in lending. The Review of Financial Studies, 23(7), 2757-2788.

Anderson, N., Potočnik, K., \& Zhou, J. (2014). Innovation and creativity in organizations: A state-of-the-science review, prospective commentary, and guiding framework. Journal of Management, 40(5), 1297-1333.

Ardic, O. P., Mylenko, N., \& Saltane, V. (2012). Access to Finance by Small and Medium Enterprises: A Cross-Country Analysis with A New Data Set. Pacific Economic Review, 17(4), 491-513.

Ashton, J. K., \& Keasey, K. (2003). Lending decision making and the Competition Commission report on the provision of banking services to small firms. Journal of Financial Regulation and Compliance, 11(1), 26-36.

Ayadi, R., \& De Groen, W. P. (2014). Banking Business Models Monitor 2014: Europe.

Ayyagari, M., Demirguc-Kunt, A., \& Maksimovic, V. (2011). Small vs. young firms across the world: contribution to employment, job creation, and growth.

Baden-Fuller, C., \& Morgan, M. S. (2010). Business models as models. Long range planning, 43(2), 156-171.

Barclay, D., Higgins, C., \& Thompson, R. (1995). The Partial Least Squares (pls) Approach to Casual Modeling: Personal Computer Adoption Ans Use as an Illustration.

Behr, P., Foos, D., \& Norden, L. (2017). Cyclicality of SME lending and government involvement in banks. Journal of Banking \& Finance, 77, 64-77.

Blundell-Wignall, A., \& Atkinson, P. (2010). Thinking beyond Basel III. OECD Journal: Financial Market Trends, 2010(1), 9-33.

Bocken, N. M. P., Short, S. W., Rana, P., \& Evans, S. (2014). A literature and practice review to develop sustainable business model archetypes. Journal of cleaner production, 65, 42-56.

Bollen, K. A. (1989). A new incremental fit index for general structural equation models. Sociological Methods \& Research, 17(3), 303-316.

Bolton, R., \& Hannon, M. (2016). Governing sustainability transitions through business model innovation: Towards a system understanding. Research Policy, 45(9), 1731-1742.

Bonini, S., Dell'Acqua, A., Fungo, M., \& Kysucky, V. (2016). Credit market concentration, relationship lending and the cost of debt. International Review of Financial Analysis, 45, 172179.

Boons, F., \& Lüdeke-Freund, F. (2013). Business models for sustainable innovation: state-of-theart and steps towards a research agenda. Journal of Cleaner Production, 45, 9-19.

Boot, A. W. (2000). Relationship banking: What do we know?. Journal of financial intermediation, 9(1), 7-25. 
Bouazza, A. B., Ardjouman, D., \& Abada, O. (2015). Establishing the factors affecting the growth of small and medium-sized enterprises in Algeria. American International Journal of Social Science, 4(2), 101-121.

Bowman, C., \& Ambrosini, V. (2003). How the resource-based and the dynamic capability views of the firm inform corporate-level strategy. British journal of management, 14(4), 289-303.

Byrne, B. M. (2001). Structural equation modeling: Perspectives on the present and the future. International Journal of Testing, 1(3-4), 327-334.

Canales, R., \& Nanda, R. (2012). A darker side to decentralized banks: Market power and credit rationing in SME lending. Journal of Financial Economics, 105(2), 353-366.

Casadesus-Masanell, R., \& Ricart, J. E. (2010). From strategy to business models and onto tactics. Long range planning, 43(2), 195-215.

Chan, F. T., \& Qi, H. J. (2003). Feasibility of performance measurement system for supply chain: a process-based approach and measures. Integrated manufacturing systems, 14(3), 179-190.

Chaplin, G., Emblow, A., \& Michael, I. (2000). Banking system liquidity: developments and issues. Financial Stability Review, 4, 93-112.

Chapman, C., \& Ward, S. (2008). Developing and implementing a balanced incentive and risk sharing contract. Construction Management and Economics, 26(6), 659-669.

Chesbrough, H., \& Rosenbloom, R. S. (2002). The role of the business model in capturing value from innovation: evidence from Xerox Corporation's technology spin-off companies. Industrial and corporate change, 11(3), 529-555.

Cull, R., \& Peria, M. S. M. (2013). Bank ownership and lending patterns during the 2008-2009 financial crisis: evidence from Latin America and Eastern Europe. Journal of Banking $\mathcal{E}$ Finance, 37(12), 4861-4878.

De Reuver, M., Bouwman, H., \& Haaker, T. (2013). Business model roadmapping: A practical approach to come from an existing to a desired business model. International Journal of Innovation Management, 17(01), 1340006.

Dhanini, F. (2007). Fear is the Key: A Behavioral Guide to Underwriting Cycles. Conn. Ins. LJ.

Diamond, D. W., \& Rajan, R. G. (2001). Liquidity risk, liquidity creation, and financial fragility: A theory of banking. Journal of political Economy, 109(2), 287-327.

Drogt, E., \& Goldberg, S. (2008). Managing Foreign Exchange Risk. Journal of Corporate Accounting and Finance, 49-57.

Edoho, F. M. (2015). Entrepreneurialism: Africa in transition. African Journal of Economic and Management Studies,6(2).

Eisenhardt, K. M., \& Martin, J. A. (2000). Dynamic capabilities: what are they?. Strategic management journal, 1105-1121.

Ennew, C. T., \& Binks, M. R. (1996). The impact of service quality and service characteristics on customer retention: small businesses and their banks in the UK. British Journal of Management, 7(3), 219-230.

Esfahani, H. N., Hossein Sobhiyah, M., \& Yousefi, V. R. (2016). Project Portfolio Selection via Harmony Search Algorithm and Modern Portfolio Theory. Procedia-Social and Behavioral Sciences, 226, 51-58.

Fornell, C., \& Larcker, D. F. (1981). Structural equation models with unobservable variables and measurement error: Algebra and statistics. Journal of marketing research, 382-388.

Friedrich von den Eichen, S., Freiling, J., \& Matzler, K. (2015). Why business model innovations fail. Journal of Business Strategy, 36(6), 29-38. 
Gehrig, T. P. (2015). Changing business models in banking and systemic risk. Albach, H., Meffert, H., Pinkwart, A. and R. Reichwald (eds.), Management of Permanent Change. Wiesbaden: Springer Fachmedien, 145-160.

Gholami, S. (2011). Value creation model through corporate social responsibility (CSR). International Journal of Business and Management, 6(9), 148.

Guo, Y., Zhou, W., Luo, C., Liu, C., \& Xiong, H. (2016). Instance-based credit risk assessment for investment decisions in P2P lending.European Journal of Operational Research, 249(2), 417-426.

Hair, J. F., Black, W. C., \& Babin, B. J. (2010). RE Anderson Multivariate data analysis: A global perspective.

Hasan, I., Jackowicz, K., Kowalewski, O., \& Kozłowski, Ł. (2017). Do local banking market structures matter for SME financing and performance? New evidence from an emerging economy. Journal of Banking \& Finance, 79, 142-158.

Hollman, K. W., \& Mohammad-Zadeh, S. (1984). Risk management in small business. Journal of Small Business Management, 22(1), 47-55.

Hryckiewicz, A., \& Kozłowski, Ł. (2017). Banking business models and the nature of financial crisis. Journal of International Money and Finance, 71, 1-24.

Hu, L. T., \& Bentler, P. M. (1999). Cutoff criteria for fit indexes in covariance structure analysis: Conventional criteria versus new alternatives. Structural equation modeling: a multidisciplinary journal, 6(1), 1-55.

Huijben, J. C. C. M., \& Verbong, G. P. J. (2013). Breakthrough without subsidies? PV business model experiments in the Netherlands.Energy Policy, 56, 362-370.

Ibrahim, M. H. (2016). Business cycle and bank lending procyclicality in a dual banking system. Economic Modelling, 55, 127-134.

Izogo, E. E. (2016). Should relationship quality be measured as a disaggregated or a composite construct?. Management Research Review, 39(1), 115-131.

Izogo, E. E., Izogo, E. E., Reza, A., Reza, A., Ogba, I. E., Ogba, I. E., ... \& Oraedu, C. (2017). Determinants of relationship quality and customer loyalty in retail banking: Evidence from Nigeria. African Journal of Economic and Management Studies, 8(2), 186-204.

Jenkinson, N. (2008). Strengthening regimes for controlling liquidity risk: some lessons from the recent turmoil.

Johnson, R. A., \& Wichern, D. W. (2002). Applied multivariate statistical analysis. Ed. New Jersey.

Jöreskog, K. G., \& Sörbom, D. (1993). LISREL 8: Structural equation modeling with the SIMPLIS command language. Scientific Software International.

Kline, R. B. (2004). Principles and Practice of Structural Equation Modeling, (Methodology In The Social Sciences).

Kraaijenbrink, J., \& Spender, J. C. (2011). Theories of the firm and their value creation assumptions. In Annual International Conference of the Strategic Management Society (pp. 69).

Lu, J. W., \& Beamish, P. W. (2001). The internationalization and performance of SMEs. Strategic management journal, 22(6-7), 565-586.

Macheka, L., Manditsera, F. A., Ngadze, R. T., Mubaiwa, J., \& Nyanga, L. K. (2013). Barriers, benefits and motivation factors for the implementation of food safety management system in the food sector in Harare Province, Zimbabwe. Food Control, 34(1), 126-131. 
Manrai, L. A., \& Manrai, A. K. (2007). A field study of customers' switching behavior for bank services. Journal of Retailing and Consumer Services, 14(3), 208-215.

Markowitz, H. (1952). Portfolio selection. The journal of finance, 7(1), 77-91.

Mason, K., \& Palo, T. (2012, September). Innovating markets by putting business models to work. In28th IMP Conference, Italy.

Meriläinen, J. M. (2016). Lending growth during the financial crisis and the sovereign debt crisis: The role of bank ownership type. Journal of International Financial Markets, Institutions and Money, 41, 168-182.

Moorman, C., \& Rust, R. T. (1999). The role of marketing. The Journal of Marketing, 180-197.

Muller, P., Gagliardi, D., Caliandro, C., Bohn, N. U., \& Klitou, D. (2014). A partial and fragile recovery: Annual report on European SMEs 2013/2014. Luxembourg: European Commission.

Nyangara, D. (2013). SME lending: Do lending technologies matter? Sample evidence from Zimbabwe.

Øiestad, S., \& Bugge, M. M. (2014). Digitisation of publishing: Exploration based on existing business models. Technological Forecasting and Social Change, 83, 54-65.

Olivero, M. P., Li, Y., \& Jeon, B. N. (2011). Competition in banking and the lending channel: Evidence from bank-level data in Asia and Latin America. Journal of Banking \& Finance, 35(3), 560-571.

Olivero, M. P., Li, Y., \& Jeon, B. N. (2011). Competition in banking and the lending channel: Evidence from bank-level data in Asia and Latin America. Journal of Banking $\mathcal{E}$ Finance, 35(3), 560-571.

Oly Ndubisi, N. (2007). Relationship marketing and customer loyalty. Marketing intelligence $\mathcal{E}$ planning, 25(1), 98-106.

Oly Ndubisi, N., Khoo-Lattimore, C., Yang, L., \& Capel, C. M. (2011). The antecedents of relationship quality in Malaysia and New Zealand. International Journal of Quality $\mathcal{E}$ Reliability Management, 28(2), 233-248.

Oprean, V. B. (2014). Business (re) Engineering: management of the risk induced constraints. Procedia-Social and Behavioral Sciences, 109, 815-826.

Osano, H. M., \& Languitone, H. (2016). Factors influencing access to finance by SMEs in Mozambique: case of SMEs in Maputo central business district. Journal of Innovation and Entrepreneurship, 5(1), 13.

Osterwalder, A., \& Pigneur, Y. (2002). An eBusiness model ontology for modeling eBusiness. BLED 2002 Proceedings, 2.

Page, C., \& Meyer, D. (1999). Applied research design for business and management. McGraw-Hill Higher Education.

Paul, J., Parthasarathy, S., \& Gupta, P. (2017). Exporting challenges of SMEs: A review and future research agenda. Journal of World Business.

Paulet, E., Parnaudeau, M., \& Abdessemed, T. (2014). The SME struggle for financing: a clampdown in European banks post-crisis.Journal of Business Strategy, 35(2), 36-45.

Perera, A., Ralston, D., \& Wickramanayake, J. (2014). Impact of off-balance sheet banking on the bank lending channel of monetary transmission: Evidence from South Asia. Journal of International Financial Markets, Institutions and Money, 29, 195-216.

Pike, S., \& Roos, G. (2004). Mathematics and modern business management. Journal of Intellectual Capital, 5(2), 243-256.

Porter, M. E. (1996). What is strategy.Published November. 
Prahalad, C. K., \& Ramaswamy, V. (2004). Co-creation experiences: The next practice in value creation. Journal of interactive marketing, 18(3), 5-14.

Priem, R. L. (2007). A consumer perspective on value creation. Academy of Management Review, 32(1), 219-235.

Qi, L., Qingling, D., Wei, S., \& Jine, Z. (2012). Modeling of risk treatment measurement model under four clusters standards (ISO 9001, 14001, 27001, OHSAS 18001). Procedia Engineering, 37, 354-358.

Qi, L., Qingling, D., Wei, S., \& Jine, Z. (2012). Modeling of risk treatment measurement model under four clusters standards (ISO 9001, 14001, 27001, OHSAS 18001). Procedia Engineering, 37, 354-358.

Rebelo, F., \& Silva, E. G. (2017). Export variety, technological content and economic performance: the case of Portugal. Industrial and Corporate Change, 26(3), 443-465.

Rebelo, M., Santos, G., \& Silva, R. (2014). Conception of a flexible integrator and lean model for integrated management systems.Total Quality Management \& Business Excellence, 25(5-6), 683-701.

Sääskilahti, J. (2016). Local bank competition and small business lending after the onset of the financial crisis. Journal of Banking \& Finance, 69, 37-51.

Santos, J. A. (2009). Do markets "discipline" all banks equally?. Journal of Financial Economic Policy, 1(1), 107-123.

Shaban, M., Duygun, M., \& Fry, J. (2016). SME's lending and Islamic finance. Is it a "win-win" situation?. Economic Modelling, 55, 1-5.

Shah, R., \& Goldstein, S. M. (2006). Use of structural equation modeling in operations management research: Looking back and forward. Journal of Operations Management, 24(2), 148-169.

Shan, J., \& Jolly, D. R. (2013). Technological innovation capabilities, product strategy, and firm performance: The electronics industry in China. Canadian Journal of Administrative Sciences/Revue Canadienne des Sciences de l'Administration, 30(3), 159-172.

So, M. C., Thomas, L. C., \& Huang, B. (2016). Lending decisions with limits on capital available: The polygamous marriage problem. European Journal of Operational Research, 249(2), 407416.

Steinherr, A. (2006). Russian banking since the crisis of 1998. Economic Change and Restructuring, 39(3-4), 235-259.

Stevenson, T., Stevenson, T., Pond, K., \& Pond, K. (2016). SME lending decisions-the case of UK and German banks: An international comparison. Studies in Economics and Finance, 33(4), 501-508.

Szczepański, R., \& Światowiec-Szczepańska, J. (2012). Risk management system in business relationships-Polish case studies.Industrial Marketing Management,41(5), 790-799.

Teece, D. J. (2007). Explicating dynamic capabilities: the nature and microfoundations of (sustainable) enterprise performance. Strategic management journal, 28(13), 1319-1350.

Teece, D. J. (2010). Business models, business strategy and innovation. Long range planning,43(2), 172-194.

Todoni, M. D. (2015). A Post-Modern Portfolio Management Approach on CEE Markets. Procedia Economics and Finance, 32, 1362-1376.

Tohidi, H. (2011). The Role of Risk Management in IT systems of organizations. Procedia Computer Science, 3, 881-887. 
Tuch, C., \& O'Sullivan, N. (2007). The impact of acquisitions on firm performance: A review of the evidence. International Journal of Management Reviews, 9(2), 141-170.

Zheng, Y., \& Zhu, Y. (2013). Bank lending incentives and firm investment decisions in China. Journal of Multinational Financial Management, 23(3), 146-165.

Zott, C., Amit, R., \& Massa, L. (2011). The business model: recent developments and future research.Journal of management, 37(4), 1019-1042.

Zuiderwijk, A., \& Janssen, M. (2014). Open data policies, their implementation and impact: A framework for comparison.Government Information Quarterly,31(1), 17-29. 